\title{
THE INFLUENCE OF VINTAGE ON HOUSE VALUE
}

\section{MICHAEL REHM, OLGA FILIPPOVA and JEREMY STONE University of Auckland}

\begin{abstract}
This research provides a significant step towards understanding the relationship between house vintage and value. This study analyses residential sales transactions in New Zealand using hedonic pricing models and uncovers evidence that a home's vintage is a commodity that commands price premiums or discounts. Vintage is found to have a nonlinear influence on sales price and this relationship differs from market to market. In particular, wealthier markets witness a greater vintage effect, with turn-of-the-century homes realising 15\% price premiums over new homes. In contrast, less wealthy markets tend to apply discounts of $20 \%$ to $40 \%$ to houses of the same vintage.
\end{abstract}

Keywords: Vintage effect, house value, hedonic pricing model, heteroskedasticity.

\section{INTRODUCTION}

Although the age of residential property is frequently included in hedonic pricing models, often as a proxy for depreciation, few empirical studies have investigated the complex relationship between a house's vintage, or period of construction, and property value. This study uses a robust database of 1996 residential real estate transactions in New Zealand's four largest markets to help fill this gap in the body of knowledge. One goal of the study is to determine the most appropriate specification for house vintage in hedonic pricing models using data from the four largest New Zealand markets. The study is also designed to explore the relationship between vintage and sales price and determine if vintage effects are consistent across markets. Lastly, the theory of vintage effect is discussed and clarifications are offered.

Existing research has defined the phenomenon of vintage-associated pricing as "vintage effect". Unfortunately, the few definitions offered for vintage effect vary. The earliest mention of the expression is by Hall $(1968,1971)$ who in studying the automobile market defines vintage effect as the reflection of "goodness" of a capital good as it was originally constituted. Randolph (1988) later suggested that vintage effect is initial unmeasured quality of location and structural characteristics associated with homes built in a given year. While Clapp and Giaccotto (1998) argue that vintage effect (age independent of physical depreciation) can be

$232 \quad$ Pacific Rim Property Research Journal, Vol 12, No 3


negative if individuals have a pure taste for newer houses as suggested by Rubin (1993), but can also be positive whenever individual tastes and preferences shift to older homes.

This paper provides a thorough review of the related literature, an explanation of the data and methodology employed to study vintage effect, and a discussion of the results and the implications of the research findings.

\section{LITERATURE REVIEW}

In a recent meta-analysis of 125 real estate research publications using hedonic pricing models by Sirmans, Macpherson and Zietz (2005), the variable age appeared in 78 articles, more than any other variable. Nevertheless, the vast majority of these studies used age as per the depreciation hypothesis to reflect the level of other housing attributes, namely unmeasured physical condition. According to the meta-analysis, age consistently has a negative effect on selling price and the average effect of age on value seems to be about $1 \%$ or less. Only a small number of empirical studies have been conducted that focus on age- or vintage-specific impacts on house value.

\section{Empirical studies focused on the impact of vintage on house value}

One of the earliest studies to focus on vintage effect was by Randolph (1988) who used rental housing unit data from the 1977 American Housing Survey (AHS) for the Detroit MSA to empirically determine if the inherent design and construction quality of particular house vintages influences gross rent. Randolph's econometric results showed that no significant vintage effect was present in the data. Nevertheless, he suggests "the assumption of stable unobserved quality is likely to be superior to ignoring vintage effects".

Rubin (1993) suggested that if consumers dislike the aesthetic, image or intangible "feel" of older units, such units should command a lower market price regardless of their physical condition. Rubin further hypothesised that a pure taste for age implies that aesthetics, not deterioration, makes older residences relatively inexpensive. In other words, a premium is paid for unit newness.

Using 1988 AHS data on owner-occupied and renter-occupied housing units from 11 MSAs, Rubin set out to isolate this "taste for newness" by controlling for unit physical condition and neighbourhood quality through 36 of the AHS's 500 collected variables. According to Rubin, this subset of variables provides a robust picture of dwelling condition and its inclusion in a hedonic pricing model should allow the age variable to capture any premium on house newness.

There are, however, four notable concerns for the design of Rubin's hedonic models: 1) variables controlling for neighbourhood quality were highly subjective and likely biased, 2) the results likely suffered from spatial autocorrelation since Pacific Rim Property Research Journal, Vol 12, No 3 
the only control for location was a dummy variable indicating whether the unit was located in the central city or a suburb, 3) the age variable was specified as linear without exploring other options such as a polynomial function, and 4) the dependent variable (value) was not a true reflection of market value, but rather the homeowner's unqualified "estimate of how much the property (house and lot) would sell for if it were for sale" (U.S. Department of Housing and Urban Development, 1990).

The results of Rubin's hedonic estimation showed that the 36 variables meant to capture unit condition and neighbourhood quality offered poor explanatory power while the age variable, meant to measure vintage effect (or 'taste for newness'), consistently held a strong negative relationship to value and rent. In addition the models' coefficients of determination $\left(\mathrm{R}^{2}\right)$ were inconsistent and relatively weak, particularly in the owner-occupied samples where they ranged from 0.24 to 0.57 . Rubin concludes that age plays a complex role in the housing market and is likely used as a rule of thumb to indicate unit condition. Given these results in context of the above-mentioned concerns with the models, interpretation of this study's findings should be made cautiously. Despite its shortcomings, however, Rubin's work was pointing in the right direction and in-part offered inspiration for the present study.

Using a dataset of sale transactions from 1984 and 1985 within Dallas County, Texas, Goodman and Thibodeau (1995) examined the influence of dwelling age specification on estimated depreciation rates and found that age of a home has a complicated, nonlinear effect on sales price. Comparing specifications of linear age against several polynomial functions of age (quadratic, cubic and quartic) the researchers found that cubic and quartic offered considerably higher explanatory power (Adjusted $\mathrm{R}^{2}$ ). This is due to the multiple turning points, or knots, offered by these higher order polynomials. The knots allow the function to better model a nonlinear relationship, such as that found by the researchers between house age and value. However, the hedonic model employed was not robust and only offered control for size of living area and date of sale, hence the results were likely subject to spatial autocorrelation and other errors from correlations between house age and omitted variables such as physical condition, lot size, socioeconomic neighbourhood characteristics, etc.

In response to these limitations, the authors extended their original hedonic model and employed similar data from 1991 to 1993 (see Goodman and Thibodeau, 1997), but still omitted any control for physical condition. Overall, the latter study does offer evidence that age effects are not linear, contrary to the specification commonly assumed in hedonic house pricing models. In their 1997 study, Goodman and Thibodeau specify the age variable as a cubic polynomial function and graph a depreciation schedule showing sharp discounts for recent vintages with a maximum discount of $70 \%$ for 1970 vintage houses when compared to new home values. This discount then gradually diminishes through succeeding vintages to a

$234 \quad$ Pacific Rim Property Research Journal, Vol 12, No 3


$10 \%$ discount around the 1930 vintage. Houses are then discounted further with increasingly earlier vintages. Although this depreciation schedule is intriguing, its interpretation is hampered by the fact that the model does not fully resolve issues with spatial autocorrelation, does not separate vintage effects from age-related physical depreciation, and does not account for levels of maintenance and capital renovations of older properties.

The most recent study specifically analyzing age-effects on house values was conducted by Clapp and Giaccotto (1998). Using a repeat sales database containing house transactions from 1981 to 1991 in Fairfax County, Virginia, the researchers created a time series of age coefficients. They concluded that there are two components of age coefficients: a cross-sectional depreciation component and a demand-side component that changes over time. The latter component is theorised by Clapp and Giaccotto as including changes in tastes for architectural features over time as well as age-related locational factors. Although it is true that changing architectural features is a vital part of vintage effect, location is not inherently related to age. Location may be correlated to house age, as well as socioeconomic status of neighbourhood residents, given the distinctive development patterns of modern cities, but failure to untangle age, location, and neighbourhood quality will likely result in spatial autocorrelation and misleading empirical findings.

Waddell, Berry and Chung (1996) employed 1993 house sales data from Dallas County, Texas to further empirically test Rubin's hypothesis that a taste for newness exists in housing markets (see Rubin, 1993). In contrast to earlier studies Waddell, Berry and Chung investigate age effects at the submarket level. As with Goodman and Thibodeau (1997), they specify age as a cubic polynomial function and they also fail to control for differences in physical condition and have similar issues with spatial autocorrelation. Waddell, Berry and Chung find that there is much variation between the 44 Dallas submarkets analyzed in terms of depreciation schedules. According to the researchers, the elite Park cities communities, for instance, witnessed value premiums for earlier vintage homes compared to new houses. Also in the "M-Street" neighbourhood with its World War II era, reproduction Victorian architecture, premiums are paid for this popular style by the market's young professional couples. On the other hand, some submarkets are in line with Rubin's hypothesis of a 'taste for newness' and discount houses with increasing vintages. Again, as with Goodman and Thibodeau $(1995,1997)$, the interpretations of the findings must be made cautiously since the hedonic model entangles vintage effect with property physical condition at time of sale, which contains unmeasured maintenance and capital renovation.

An associated body of literature relates to depreciation and maintenance of houses. Although numerous studies have been conducted on residential depreciation, most employ the hedonic model for house value using age of the dwelling as a proxy for depreciation. Malpezzi, Ozanne and Thibodeau (1987) offer a good review of this 
literature. Few studies, however, account for maintenance and renovation when investigating depreciation. Since depreciation includes all of the factors that cause a house to decline in value, controlling for maintenance and renovation is useful in better understanding the impact that age itself has on value. Lowry (1960) argued, for instance, that "with normal maintenance the quality of a dwelling unit could be preserved indefinitely". While Margolis (1981) investigated whether a house will provide the same quantity of service over time under normal circumstances, if "normal" or reasonable maintenance is provided. He considered the possibility of spending that would restore the structure to its original condition in every period thus eliminating depreciation. Arnott, Davidson, and Pines (1983) suggest that a property may even appreciate in value as a result of certain maintenance decisions. Chinloy (1980) separates gross depreciation from depreciation net of maintenance and finds that depreciation rates would double in the absence of maintenance. Knight and Sirmans (1996) analyze the effect of maintenance on the depreciation rates of housing using a time-series of data restricted to a concise neighbourhood to avoid issues of spatial autocorrelation. They produce a hedonic pricing model using data from 775 home sales in Louisiana between 1985 and 1993. The study design is sound aside from a critical measurement: house maintenance. The level of maintenance was based on broker remarks associated with the MLS listings. These remarks, such as "handyman's special", were likely biased and written to motivate a successful sale, rather than reflect the factual condition of the dwelling. They cannot be equated to measures provided by professionals qualified to judge a property's physical condition such as a valuer or building inspector. These broker remarks, coded as dummy variables, did result in the expected signs, but their impacts on value were negligible and had little influence on the model. Instead, the age variable dominated and assumed the role of proxy for depreciation.

In summary, a handful of empirical studies have focused on age- and vintageeffects and how they influence house values. Other age-specific studies not elaborated here include papers by Epley (1990), Guasch and Marshall (1985), Muth (1973), Do and Grudnitski (1993) and Sabella (1974, 1975). None, however, have successfully separated vintage effect from other age-related effects such as physical condition. The present study sets out to do so by specifically controlling for physical condition at time of sale and by minimizing spatial autocorrelation through use of controls for location and socioeconomic neighbourhood characteristics.

\section{Heteroskedasticity in hedonic house price models}

Homoskedasticity is an important assumption in ordinary least squares (OLS) regression. Although the estimator of the regression parameters in OLS regression is unbiased when the homoskedasticity assumption is violated, the estimator of the covariance matrix of the parameter estimates can be biased and inconsistent under heteroskedasticity, which can produce inaccurate significance tests and confidence intervals. Long and Ervin (2000) propose the use of a heteroskedasticity consistent covariance matrix, or HCCM, to effectively avoid the adverse effects of

$236 \quad$ Pacific Rim Property Research Journal, Vol 12, No 3


heteroskedasticity in linear regression models, even when nothing is known about the form of heteroskedasticity. Long and Ervin test the effectiveness of four HCCMs originally developed by White (1980) and found that the HCCM dubbed $\mathrm{HC} 3$ is superior for both small and large sample sizes. Hayes and Cai (in review) further explore the use of heteroskedastic consistent (HC) estimators and developed a set of macros for two popular statistical software packages, SPSS and SAS, that allow researchers to perform OLS regressions employing the $\mathrm{HC}$ estimators developed by White. Using these macros, the present study utilizes HC3 estimators in its multiple regression analyses to accommodate heteroskedasticity, which frequently hampers hedonic pricing models and is often related to house age as documented by Goodman and Thibodeau (1995, 1997, 1998). They found that the decisions made about construction and renovations imply that heteroskedasticity is related to house age. In their studies, Goodman and Thibodeau demonstrated the use of an iterative general least squares (GLS) procedure to accommodate heteroskedasticity, thus increasing model efficiency through reduction of estimated standard errors and increase of the accuracy of coefficient point estimates.

\section{DATA AND METHODOLOGY}

The main source of data for this study is the 1996 official database of all detached or semi-detached residential real estate transactions in New Zealand. The country's four largest markets were analyzed: Auckland City, Wellington City, Christchurch City and Dunedin City. In the case of the Auckland, the researchers only analysed sales within the Auckland City territorial authority rather than transactions throughout the entire Auckland Region, which further includes the cities of North Shore, Waitakere, Manakau and Papakura. This is because Auckland City is the oldest urban area in the region and offers a more comparable distribution of house vintages as found in the other markets being studied. See Table 1 for specific distributions for 1996 sales transactions analysed in this study.

Table 1: Percentage Distribution of Analysed 1996 Sales Transactions by House Vintage

\begin{tabular}{lllllllllllll}
\hline Market & Pre & & & & & & & & & & \\
& $\mathbf{1 8 9 0}$ & $\mathbf{1 8 9 0}$ & $\mathbf{1 9 0 0}$ & $\mathbf{1 9 1 0}$ & $\mathbf{1 9 2 0}$ & $\mathbf{1 9 3 0}$ & $\mathbf{1 9 4 0}$ & $\mathbf{1 9 5 0}$ & $\mathbf{1 9 6 0}$ & $\mathbf{1 9 7 0}$ & $\mathbf{1 9 8 0}$ & $\mathbf{1 9 9 0}$ \\
\hline Auckland City & 1.5 & 2.2 & 7.9 & 8.7 & 19.7 & 8.7 & 11.1 & 16.8 & 12.9 & 4.8 & 4.4 & 1.3 \\
$\begin{array}{l}\text { Wellington City } \\
\text { Christchurch }\end{array}$ & 0.1 & 0.4 & 9.2 & 8.2 & 15.3 & 10.2 & 9.2 & 11.0 & 15.6 & 10.5 & 8.1 & 2.1 \\
City & & & & & & & & & & & & \\
Dunedin City & 2.6 & 4.0 & 9.2 & 8.6 & 12.2 & 10.2 & 9.4 & 15.5 & 13.1 & 9.5 & 4.3 & 1.3 \\
\hline
\end{tabular}

Transactions within the official database were excluded from analysis if they were suspected to include data entry errors. Specifically, houses were removed if the 
floor area was less than 30 square metres or over 360 square metres, if lot size was below 150 square metres or over 3,000 square metres, if the property contained more than 6 on-site car parks or had any missing data for any of the variables of interest. Also transactions were deleted that were flagged as outliers within the dataset, had leasehold rather than freehold interests, were classified as being other than a standard residential dwelling (e.g. house with income, rental flat, etc) or were deemed not to reflect an arm's length transaction by the valuer who collected the data.

For each city, a series of three hedonic regressions were conducted. The models differed only in specification of house vintage. Model One followed the most common specification using a linear, continuous age variable input as year of construction. Model Two converted the year of construction into a discrete variable by aggregating years into decades. The decade variable was then placed into the model as a cubic polynomial function. In order to avoid problems with collinearity among the three variables (decade, decade ${ }^{2}$ and decade ${ }^{3}$ ), the decade of construction was first centred about the mean (see Bates and Watts, 1988, p. 78 for discussion of scaling and centring). The mean years of construction for each city are as follows: Auckland (1942), Wellington (1946), Christchurch (1953) and Dunedin (1940). Model Three specified vintage as a series of dummy variables by decade of construction. The default category was set as 1990s and the last vintage category was determined by the number of observations per vintage within each city. For instance, within Auckland and Christchurch, vintages are aggregated from the 1870 s and prior, while in Wellington and Dunedin, which are younger cities, vintages are aggregated from the 1890 s and 1880 s respectively.

The expected results are that Models Two and Three will offer superior explanatory power, measured in terms of Adjusted $\mathrm{R}^{2}$, over the linear specification of Model One. Having controlled for differences in physical condition, accessibility and neighbourhood quality, the vintage variable(s) will capture any premiums or discounts (vintage effect) based on the market's desire for the vintage's unmeasured physical characteristics (construction quality, architectural style and design features), which is expected to unveil a nonlinear relationship between vintage and house price. Hence, the polynomial function and dummy variables will better adjust to shifts in vintage effect than will a single linear variable measuring vintage.

In terms of variations of vintage effect across vintages and markets, it is anticipated that all markets will hold similar patterns given the homogeneity of vintageassociated architectural styles across New Zealand.

\section{Hedonic specification}

Let $\mathrm{P}(\mathbf{X})=\mathrm{P}(\mathbf{L}, \mathbf{S}, \mathbf{N}, \mathbf{A}, \mathbf{E}, \mathbf{C}, \mathbf{V})$ be a house price function that maps housing characteristics onto market value. This function maps the following characteristics of land, L (site area, on-site car parks and landscaping); structural characteristics, S 
(floor area); neighbourhood characteristics, $\mathbf{N}$ (per capita income and \% European); accessibility, A (distance to $\mathrm{CBD}$ ); environmental externalities, $\mathbf{E}$ (water view and quality of surrounding improvements); physical condition, C (condition of exterior walls and interior condition of fixtures and finishes) and vintage, $\mathbf{V}$ (year of construction). Given the data is limited to transactions in 1996, the time variable is omitted from the hedonic models.

Parameters of hedonic equations are frequently estimated by using a semilogarithmic functional form to conform to rules of parametric tests. This specification regresses the natural log of sales price, net of chattels, on a linear combination of housing characteristics. The semilog functional form is given by

$$
\mathbf{P}=e^{\mathbf{X} \mathbf{b}+\mathbf{e}}
$$

where $\mathrm{P}$ is the market value, $\mathrm{X}$ is a vector of housing characteristics, $\mathrm{b}$ is the vector of unknown hedonic coefficients, and e is the residual. Taking natural logs of Equation (1) yields the transformed equation:

$$
\mathbf{Z}=\ln \mathbf{P}=\mathbf{X b}+\mathrm{e},
$$


The empirical hedonic specification used here is:

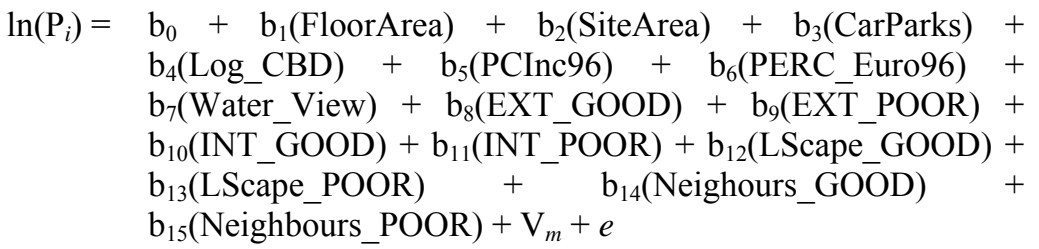

where: $P_{i}$

FloorArea
SiteArea
CarParks
Log_CBD
PCInc96
PERC_Euro96
Water_View
EXT_GOOD
EXT_POOR

INT_GOOD

INT_POOR

LScape_GOOD

LScape_POOR

Neighbours_GOOD
$=$ net sales price of the $i$ th house;

$=$ total floor area in square metres;

$=$ area of the land plot in square metres;

$=$ number of on-site car parks;

$=$ natural $\log$ of the distance between the house and Central Business District (CBD)

$=$ per capita income of the 1996 NZ Census Area Unit in which the house is located;

$=$ percentage of Area Unit population that is European

$=$ dummy variable for whether or not the house has a water view

$=$ dummy variable for whether the house's exterior walls were coded as being in 'Good' condition by the valuer

$=$ dummy variable for whether the house's exterior walls were coded as being in 'Fair' or 'Poor' condition by the valuer (default category is 'Average')

$=$ dummy variable for whether the house's interior fixtures and finishes were coded as being in 'Good' condition by the valuer

$=$ dummy variable for whether the house's interior fixtures and finishes were coded as being in 'Poor' condition by the valuer (default category is 'Average')

$=$ dummy variable for whether the house's landscaping was coded as being 'Good' quality by the valuer

$=$ dummy variable for whether the house's landscaping was coded as being 'Poor' quality by the valuer (default category is 'Average')

$=$ dummy variable for whether the house's 
immediate surroundings (namely neighbouring improvements) were coded as being 'Good' quality by the valuer

Neighbours_POOR $=$ dummy variable for whether the house's immediate surroundings were coded as being 'Poor' quality by the valuer (default category is 'Average')

$\mathbf{V}_{m} \quad=\quad$ vintage for the $m$ th hedonic model (1 to 3 )

e $\quad=$ random error.

The three specifications for vintage being compared are linear (Model One), cubic polynomial (Model Two) and dummy (Model Three). As per each of the three models, $\mathbf{V}_{m}$ is defined as

$\mathbf{V}_{1}=\quad b_{16}($ Year_Built $)$

where: Year_Built $\quad=$ year house was constructed

$\mathbf{V}_{2}=\quad b_{16}($ Decade_centered $)+b_{17}($ Decade_c2 $)+b_{18}($ Decade_c3 $)$

where: Decade_centred $=$ Decade the house was constructed minus the mean year of construction for the given

Decade_c2 city (e.g. Auckland)

Decade_c3 $=$ Decade_centred ${ }^{3}$

$\mathbf{V}_{3}=\quad b_{16}(\mathrm{D} 1980)+b_{17}(\mathrm{D} 1970)+b_{18}(\mathrm{D} 1960)+b_{19}(\mathrm{D} 1950)+b_{20}(\mathrm{D} 1940)$

$+b_{21}(\mathrm{D} 1930)+b_{22}(\mathrm{D} 1920)+\mathrm{b}_{23}(\mathrm{D} 1910)+\mathrm{b}_{24}(\mathrm{D} 1900)+$

$\mathrm{b}_{25}(\mathrm{D} 1890)+\mathrm{b}_{26}(\mathrm{D} 1880)+\mathrm{b}_{27}\left(\mathrm{D} 1870 \_\mathrm{DN}\right)$

where: D1980... = series of dummy variables for decade of house construction (default category is 1990s)

D1870_DN = final dummy variable that aggregates all prior vintages (decades) (e.g. 1870s and earlier vintages) 


\section{RESULTS}

Figure 1 provides a line graph, derived from the polynomial function within Model Two, showing vintage effect in each of the four markets. Setting 1990s vintage as the benchmark, the graph shows premiums and discounts associated with each vintage. In contrast to what was expected, the markets differ considerably in respect to pattern of vintage effect. Both Auckland and Wellington share a similar pattern in terms of vintage effect, with discounts of up to $15 \%$ associated to vintages in the 1980s through 1960s, the 1930s vintage are of comparable value with the current vintage (1990s), premiums are then offered to houses of proceeding vintages, with top premiums paid for turn-of-the-century homes, and, lastly, premiums gradually decline for pre-1900 vintages. Dunedin, however, is quite dissimilar. Vintage-associated discounts are sharp from the 1980s through 1940s vintages. The discounts then remain steady, yet slightly increasing, for earlier vintages. Christchurch's pattern lies in between with a sharp decline to the 1940 s vintage followed by a reduction in price discounts for earlier vintages.

Using the 1900s vintage as a point of comparison, houses from this time period receive a $15 \%$ price premium over current 1990s vintage homes in Auckland and Wellington, while in Christchurch and Dunedin the same 1900s vintage is discounted roughly $20 \%$ and $40 \%$, respectively.

\section{Figure 1: Vintage Effect: Based on Polynomial Function within Model Two}




Table 2 provides a comparison of the explanatory power (Adjusted $\mathrm{R}^{2}$ ) between the linear specification of vintage (Model One) and the cubic polynomial and dummy variable specifications, Models Two and Three. The results were more consistent than the pattern of vintage effect itself, but not entirely uniform across markets. Of the four cities, Wellington, Christchurch and Dunedin demonstrated considerable improvement in explanatory power of the two nonlinear specifications. The change in Adjusted $\mathrm{R}^{2}$ ranged from $0.8 \%$ to $2.1 \%$. This is a noteworthy enhancement, given that the meta-analysis conducted by Sirmans, Macpherson and Zietz (2005) found the average effect of age on value is $1 \%$ or less. In contrast, the hedonic models produced for Auckland City show that the linear Model One provides slightly greater explanatory power than Models Two and Three. This can be explained inpart due to the fact that the relationship between price and vintage is more linear among the Auckland data than with the other three markets. Furthermore, the linear specification (Model One) of vintage is a continuous variable, while the cubic polynomial (Model Two) and dummy variables (Model Three) measure vintage in terms of decades rather than years.

Table 2: Summary of Regression Analyses: Change in Explanatory Power from Model 1 to Models 2 and 3

\begin{tabular}{llcllc}
\hline Market & Model & $\mathbf{R}^{2}$ & Adj. $\mathbf{R}^{2}$ & $\begin{array}{c}\text { Std. } \\
\text { Error of } \\
\text { Estimate }\end{array}$ & $\begin{array}{c}\text { Change in } \\
\text { Adj. } \mathbf{R}^{2}\end{array}$ \\
\hline Auckland City & 1 & .749 & .748 & .234 & - \\
$N=4,161$ & 2 & .744 & .743 & .236 & $-0.50 \%$ \\
& 3 & .746 & .745 & .235 & $-0.30 \%$ \\
\hline Wellington City & 1 & .764 & .763 & .198 & - \\
$N=3,128$ & 2 & .781 & .780 & .191 & $1.70 \%$ \\
& 3 & .786 & .784 & .189 & $2.10 \%$ \\
\hline Christchurch City & 1 & .777 & .776 & .188 & - \\
$N=6,812$ & 2 & .791 & .791 & .183 & $1.50 \%$ \\
& 3 & .793 & .792 & .182 & $1.60 \%$ \\
\hline Dunedin City & 1 & .684 & .682 & .220 & - \\
$N=2,217$ & 2 & .692 & .690 & .217 & $0.80 \%$ \\
& 3 & .698 & .695 & .216 & $1.30 \%$ \\
\hline
\end{tabular}

Tables 3 through 6 contain the results from the hedonic regressions, which employed heteroskedastic consistent (HC) estimators to accommodate heteroskedasticity present in the data. The R-squared of the models are good, ranging from .684 to .793 , with Dunedin offering the lowest explanatory power and Christchurch offering the highest. This is somewhat expected given Dunedin is the smallest city being studied and offers the lowest number of observations, 
while Christchurch is the largest in terms of population and provides a larger dataset.

The direction and relative magnitude of the estimated coefficients was largely as expected with a few exceptions. The independent variables for floor area and number of on-site car parks maintained significant positive relationships with net sales price in all markets. Site area was nearly as consistent but was not found to be significant in Wellington or Dunedin. The control variable for accessibility measured as the natural log of distance to the Central Business District (CBD) consistently held a significant negative relationship in all markets. The impact of accessibility was considerably greater in Auckland and Wellington. The two variables controlling for differences in neighbourhood characteristics, per capita income and percentage European, provided varying relationships across markets. In the two largest markets, Auckland and Christchurch, both variables held significant positive impacts on sales price. In Wellington, neighbourhood per capita income followed suit, but the race variable was insignificant and negatively correlated with house price. The Dunedin data showed a weak positive relationship in both variables, with only the cubic model holding a statistically significant relationship between per capita income and net sales price.

The variables accounting for environmental externalities, water view and quality of surrounding improvements maintained their expected signs and were statistically significant in all four markets. The pair of dummy variables capturing the quality of site landscaping also maintained the expected signs and were significant in all markets, with the exception of Dunedin where houses with above average landscaping did not command significantly higher prices.

A critical component of this study is providing adequate control for physical condition of each home sold. This was captured in two pairs of dummy variables accounting for the condition of exterior walls and interior finishes and fixtures. Across all markets the variables provided the expected signs. They were also consistently significant with the exception of the cubic model for Auckland, which found houses with exterior walls in 'good' condition did not command significant price premiums over those of 'average' condition. In addition, the Christchurch data suggests that house prices are not significantly reduced due to poor condition of exterior walls or interior finishes and fixtures.

The sets of independent variables capturing vintage effect disclose a major difference between these markets in terms of price premiums and discounts offered to houses of different vintage. On one hand, the wealthier cities, Auckland and Wellington, witness considerable price premiums for earlier vintages. The linear model (Model One), measuring vintage in terms of year of construction, finds a significant negative relationship between vintage and sales price for these two cities. Overall, price increases with increasingly earlier vintages after accounting for differences in physical depreciation and location factors. The opposite is true 
with Christchurch and Dunedin. In these two markets, the linear variable, YearBuilt, holds a significant positive effect on sales price. In other words, earlier vintages are discounted relative to more current vintages. This same fundamental difference between the two pairs of cities is reinforced by the nonlinear models, with vintage captured by a cubic function (Model Two) as well as a series of dummy variables (Model Three). 
Table 3: Regression Analysis: Auckland City

\begin{tabular}{|c|c|c|c|c|c|c|c|c|c|}
\hline \multirow[b]{2}{*}{ Variable } & \multicolumn{2}{|c|}{ Model One (Linear) } & \multirow[b]{2}{*}{ T-Value } & \multicolumn{2}{|c|}{ Model Two (Cubic) } & \multirow[b]{2}{*}{ T-Value } & \multicolumn{2}{|c|}{ Model Three (Dummy) } & \multirow[b]{2}{*}{ T-Value } \\
\hline & Estimate & HCSE & & Estimate & HCSE & & Estimate & HCSE & \\
\hline Intercept & 17.683 & .454 & $38.928^{*}$ & 12.790 & .136 & $94.145^{*}$ & 12.833 & .140 & 91.396* \\
\hline FloorArea & $3.19 \mathrm{E}-03$ & $1.50 \mathrm{E}-04$ & $21.280^{*}$ & $2.94 \mathrm{E}-03$ & $1.64 \mathrm{E}-04$ & $17.934 *$ & $2.95 \mathrm{E}-03$ & $1.69 \mathrm{E}-04$ & $17.511 *$ \\
\hline SiteArea & $2.07 \mathrm{E}-04$ & $2.20 \mathrm{E}-05$ & $9.398^{*}$ & $2.33 \mathrm{E}-04$ & $2.22 \mathrm{E}-05$ & $10.536^{*}$ & $2.34 \mathrm{E}-04$ & $2.21 \mathrm{E}-05$ & $10.596^{*}$ \\
\hline CarParks & .033 & .006 & $5.181^{*}$ & .036 & .006 & $5.512^{*}$ & .035 & .006 & $5.381 *$ \\
\hline $\log _{-} C B D$ & -.177 & .015 & $-11.849^{*}$ & -.174 & .015 & $-11.660^{*}$ & -.172 & .015 & $-11.504 *$ \\
\hline PCInc96 & $1.41 \mathrm{E}-05$ & $1.74 \mathrm{E}-06$ & 8.104* & $1.43 \mathrm{E}-05$ & $1.73 \mathrm{E}-06$ & $8.289^{*}$ & $1.43 \mathrm{E}-05$ & $1.73 \mathrm{E}-06$ & $8.256^{*}$ \\
\hline PERC_Euro96 & .453 & .048 & $9.446^{*}$ & .423 & .048 & $8.794 *$ & .436 & .048 & $9.105^{*}$ \\
\hline Water_View & .125 & .015 & $8.106^{*}$ & .130 & .015 & $8.461 *$ & .131 & .015 & $8.531^{*}$ \\
\hline$E X T_{-} \bar{G} O O D$ & .035 & .008 & $4.329 *$ & .014 & .008 & 1.670 & .021 & .008 & $2.549^{*}$ \\
\hline EXT_POOR & -.141 & .024 & $-5.801 *$ & -.143 & .024 & $-5.873 *$ & -.145 & .024 & $-5.918 *$ \\
\hline INT_GOOD & .126 & .013 & $9.581 *$ & .114 & .013 & $8.814 *$ & .118 & .013 & $9.105^{*}$ \\
\hline INT_POOR & -.067 & .014 & $-4.762 *$ & -.062 & .014 & $-4.351 *$ & -.065 & .014 & $-4.486^{*}$ \\
\hline LScape_GOOD & .039 & .012 & $3.182^{*}$ & .040 & .013 & $3.145^{*}$ & .040 & .013 & $3.123^{*}$ \\
\hline LScape_POOR & -.050 & .017 & $-3.024 *$ & -.069 & .017 & $-4.042 *$ & -.059 & .017 & $-3.473 *$ \\
\hline Neighbours_GOOD & .114 & .014 & $8.354 *$ & .123 & .015 & $8.209^{*}$ & .125 & .015 & $8.408^{*}$ \\
\hline Neighbours_POOR & -.079 & .014 & $-5.576 *$ & -.096 & .014 & $-6.667 *$ & -.091 & .015 & $-6.254 *$ \\
\hline Year_Built & $-2.50 \mathrm{E}-03$ & $2.52 \mathrm{E}-04$ & $-9.914 *$ & & & & & & \\
\hline Decāe_centred & & & & $-3.93 \mathrm{E}-03$ & $3.17 \mathrm{E}-04$ & $-12.371^{*}$ & & & \\
\hline Decade_c2 & & & & $4.71 \mathrm{E}-05$ & 7.62E-06 & $6.183^{*}$ & & & \\
\hline Decade_c3 & & & & $1.05 \mathrm{E}-06$ & $1.60 \mathrm{E}-07$ & $6.570^{*}$ & & & \\
\hline$D 1980$ & & & & & & & -.172 & .038 & $-4.578 *$ \\
\hline D1970 & & & & & & & -.149 & .037 & $-4.051 *$ \\
\hline D1960 & & & & & & & -.115 & .034 & $-3.365^{*}$ \\
\hline D1950 & & & & & & & -.084 & .034 & $-2.464 *$ \\
\hline D1940 & & & & & & & -.071 & .034 & $-2.067 * *$ \\
\hline D1930 & & & & & & & -.016 & .036 & -0.448 \\
\hline D1920 & & & & & & & .001 & .036 & 0.023 \\
\hline D1910 & & & & & & & .088 & .038 & $2.342^{* *}$ \\
\hline D1900 & & & & & & & .102 & .040 & $2.561^{*}$ \\
\hline D1890 & & & & & & & .117 & .045 & $2.613^{*}$ \\
\hline D1880 & & & & & & & .071 & .056 & 1.282 \\
\hline D1870_DN & & & & & & & .042 & .052 & 0.807 \\
\hline \multicolumn{10}{|l|}{ Model Summaries } \\
\hline R2 & & .749 & & & .744 & & & .746 & \\
\hline Adj. R2 & & .748 & & & .743 & & & .745 & \\
\hline Std. Error of Estimate & & .234 & & & .236 & & & .235 & \\
\hline Model F-Value & & 576.36 & & & 508.12 & & & 350.86 & \\
\hline
\end{tabular}

Notes: Dependent Variable $=$ Natural log of Net Sales Price; HCSE $=$ Heteroskedastic-Consistent Standard Error; $\mathrm{N}=4,161$.

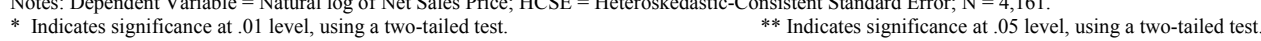


Table 4: Regression Analysis: Wellington City

\begin{tabular}{|c|c|c|c|c|c|c|c|c|c|}
\hline \multirow[b]{2}{*}{ Variable } & \multicolumn{3}{|c|}{ Model One (Linear) } & \multicolumn{3}{|c|}{ Model Two (Cubic) } & \multicolumn{3}{|c|}{ Model Three (Dummy) } \\
\hline & Estimate & HCSE & T-Value & Estimate & HCSE & T-Value & Estimate & HCSE & T-Value \\
\hline Intercept & 19.000 & .376 & $50.547^{*}$ & 12.273 & .082 & $148.820^{*}$ & 12.378 & .088 & $141.126^{*}$ \\
\hline FloorArea & $4.12 \mathrm{E}-03$ & $1.16 \mathrm{E}-04$ & $35.701^{*}$ & $4.13 \mathrm{E}-03$ & $1.13 \mathrm{E}-04$ & $36.606^{*}$ & $4.20 \mathrm{E}-03$ & $1.13 \mathrm{E}-04$ & $37.357^{*}$ \\
\hline SiteArea & $1.09 \mathrm{E}-05$ & $2.01 \mathrm{E}-05$ & 0.543 & $2.45 \mathrm{E}-05$ & $1.97 \mathrm{E}-05$ & 1.245 & $1.82 \mathrm{E}-05$ & $2.00 \mathrm{E}-05$ & 0.907 \\
\hline CarParks & .058 & .006 & $10.241^{*}$ & .054 & .005 & $9.938^{*}$ & .056 & .005 & $10.151^{*}$ \\
\hline $\log _{-} C B D$ & -.140 & .009 & $-15.779^{*}$ & -.134 & .008 & $-15.864^{*}$ & -.132 & .008 & $-15.774 *$ \\
\hline PCInc96 & $1.11 \mathrm{E}-05$ & $1.23 \mathrm{E}-06$ & $9.051^{*}$ & $1.05 \mathrm{E}-05$ & $1.17 \mathrm{E}-06$ & $8.974 *$ & $9.84 \mathrm{E}-06$ & $1.18 \mathrm{E}-06$ & $8.339^{*}$ \\
\hline PERC_Euro96 & -.162 & .074 & $-2.198 * *$ & -.079 & .073 & -1.083 & -.060 & .072 & -0.832 \\
\hline Water_View & .094 & .010 & $9.134^{*}$ & .088 & .010 & $8.661^{*}$ & .086 & .010 & $8.539^{*}$ \\
\hline EXT_GOOD & .069 & .008 & $8.288^{*}$ & .051 & .008 & $6.371 *$ & .050 & .008 & $6.300^{*}$ \\
\hline EXT_POOR & -.097 & .020 & $-4.898^{*}$ & -.095 & .020 & $-4.709^{*}$ & -.088 & .020 & $-4.420^{*}$ \\
\hline$I N T \_G O O D$ & .127 & .016 & $7.868^{*}$ & .104 & .015 & $6.962 *$ & .099 & .015 & $6.695^{*}$ \\
\hline INT_POOR & -.128 & .038 & $-3.374 *$ & -.141 & .037 & $-3.805^{*}$ & -.142 & .039 & $-3.683 *$ \\
\hline LScape_GOOD & .070 & .010 & $6.677^{*}$ & .081 & .010 & $8.081 *$ & .081 & .010 & $8.199 *$ \\
\hline LScape_POOR & -.050 & .013 & $-3.877 *$ & -.078 & .012 & $-6.252^{*}$ & -.078 & .012 & $-6.238^{*}$ \\
\hline Neighbours_GOOD & .105 & .011 & $9.733^{*}$ & .096 & .010 & $9.274^{*}$ & .097 & .010 & $9.338^{*}$ \\
\hline Neighbours_POOR & -.071 & .010 & $-7.346^{*}$ & -.070 & .009 & $-7.424 *$ & -.067 & .009 & $-7.175^{*}$ \\
\hline Year_Built & $-3.38 \mathrm{E}-03$ & 2.13E-04 & $-15.890^{*}$ & & & & & & \\
\hline Decade_centred & & & & $-5.69 \mathrm{E}-03$ & $5.09 \mathrm{E}-04$ & $-11.174 *$ & & & \\
\hline Decade_c2 & & & & 7.92E-05 & $6.81 \mathrm{E}-06$ & $11.630^{*}$ & & & \\
\hline Decade_c3 & & & & $2.15 \mathrm{E}-06$ & $3.74 \mathrm{E}-07$ & $5.751^{*}$ & & & \\
\hline$D 1980$ & & & & & & & -.130 & .023 & $-5.627^{*}$ \\
\hline D1970 & & & & & & & -.213 & .023 & $-9.281 *$ \\
\hline$D 1960$ & & & & & & & -.179 & .022 & $-7.991 *$ \\
\hline D1950 & & & & & & & -.147 & .024 & $-6.057 *$ \\
\hline$D 1940$ & & & & & & & -.054 & .025 & $-2.147 * *$ \\
\hline D1930 & & & & & & & .039 & .025 & 1.596 \\
\hline$D 1920$ & & & & & & & .025 & .024 & 1.051 \\
\hline D1910 & & & & & & & .068 & .026 & $2.570^{*}$ \\
\hline$D 1900$ & & & & & & & .100 & .027 & $3.624 *$ \\
\hline & & & & & & & .117 & .059 & $1.980^{* *}$ \\
\hline \multicolumn{10}{|l|}{ Model Summaries } \\
\hline & & .764 & & & .781 & & & .786 & \\
\hline Adj. R2 & & .763 & & & .780 & & & .784 & \\
\hline Std. Error of Estimate & & .198 & & & .191 & & & .189 & \\
\hline Model F-Value & & 513.28 & & & 504.28 & & & 388.58 & \\
\hline
\end{tabular}


Table 5: Regression Analysis: Christchurch City

\begin{tabular}{|c|c|c|c|c|c|c|c|c|c|}
\hline \multirow[b]{2}{*}{ Variable } & \multicolumn{3}{|c|}{ Model One (Linear) } & \multicolumn{3}{|c|}{ Model Two (Cubic) } & \multicolumn{3}{|c|}{ Model Three (Dummy) } \\
\hline & Estimate & HCSE & T-Value & Estimate & HCSE & T-Value & Estimate & HCSE & T-Value \\
\hline Intercept & 8.332 & .268 & $31.062^{*}$ & 10.464 & .066 & $157.943^{*}$ & 10.715 & .071 & $150.805^{*}$ \\
\hline FloorArea & $4.54 \mathrm{E}-03$ & $1.05 \mathrm{E}-04$ & $43.086^{*}$ & $3.95 \mathrm{E}-03$ & $1.07 \mathrm{E}-04$ & $36.907^{*}$ & $3.93 \mathrm{E}-03$ & $1.08 \mathrm{E}-04$ & $36.354 *$ \\
\hline SiteArea & $1.27 \mathrm{E}-04$ & $1.53 \mathrm{E}-05$ & $8.293^{*}$ & $1.73 \mathrm{E}-04$ & $1.56 \mathrm{E}-05$ & $11.140^{*}$ & $1.77 \mathrm{E}-04$ & $1.58 \mathrm{E}-05$ & $11.220^{*}$ \\
\hline CarParks & .047 & .004 & $11.998^{*}$ & .048 & .004 & $12.699^{*}$ & .047 & .004 & $12.329^{*}$ \\
\hline $\log _{-} C B D$ & -.031 & .007 & $-4.612^{*}$ & -.023 & .007 & $-3.393^{*}$ & -.021 & .007 & $-3.120^{*}$ \\
\hline PCInc96 & 3.33E-05 & $1.20 \mathrm{E}-06$ & $27.778 *$ & $3.47 \mathrm{E}-05$ & $1.16 \mathrm{E}-06$ & $30.000^{*}$ & $3.47 \mathrm{E}-05$ & $1.17 \mathrm{E}-06$ & $29.792^{*}$ \\
\hline PERC_Euro96 & .179 & .060 & $2.965^{*}$ & .181 & .057 & $3.146^{*}$ & .163 & .058 & $2.810^{*}$ \\
\hline Water_View & .060 & .021 & $2.813^{*}$ & .064 & .022 & $2.954 *$ & .064 & .021 & $3.005^{*}$ \\
\hline EXT_GOOD & .050 & .005 & $9.283^{*}$ & .019 & .005 & $3.609 *$ & .021 & .005 & $3.870^{*}$ \\
\hline EXT_POOR & -.030 & .016 & -1.904 & -.053 & .015 & $-3.464 *$ & -.052 & .015 & $-3.356^{*}$ \\
\hline INT_GOOD & .043 & .011 & $3.890^{*}$ & .055 & .011 & $5.069^{*}$ & .054 & .011 & $4.969^{*}$ \\
\hline INT_POOR & -.015 & .016 & -0.941 & -.059 & .015 & $-3.879 *$ & -.061 & .015 & $-4.007 *$ \\
\hline LScape_GOOD & .034 & .007 & $5.039^{*}$ & .053 & .007 & $7.916^{*}$ & .055 & .007 & $8.107 *$ \\
\hline LScape_POOR & -.056 & .014 & $-3.985^{*}$ & -.067 & .014 & $-4.865^{*}$ & -.065 & .014 & $-4.696^{*}$ \\
\hline Neighbours_GOOD & .139 & .008 & $16.935^{*}$ & .125 & .008 & $15.271^{*}$ & .124 & .008 & $15.068 *$ \\
\hline Neighbours_POOR & -.092 & .008 & $-12.052 *$ & -.099 & .008 & $-13.144^{*}$ & -.096 & .008 & $-12.775^{*}$ \\
\hline Year_Built & $1.14 \mathrm{E}-03$ & $1.50 \mathrm{E}-04$ & $7.620^{*}$ & & & & & & \\
\hline Decäe_centred & & & & $1.94 \mathrm{E}-03$ & $1.95 \mathrm{E}-04$ & $9.907^{*}$ & & & \\
\hline Decade_c2 & & & & $9.78 \mathrm{E}-05$ & $4.64 \mathrm{E}-06$ & $21.065^{*}$ & & & \\
\hline Decade_c3 & & & & 7.86E-07 & $8.90 \mathrm{E}-08$ & $8.839^{*}$ & & & \\
\hline$D 1980$ & & & & & & & -.105 & .011 & $-9.956^{*}$ \\
\hline D1970 & & & & & & & -.203 & .010 & $-20.555^{*}$ \\
\hline$D 1960$ & & & & & & & -.214 & .010 & $-20.889^{*}$ \\
\hline$D 1950$ & & & & & & & -.265 & .012 & $-22.991 *$ \\
\hline D1940 & & & & & & & -.278 & .014 & $-19.342 *$ \\
\hline D1930 & & & & & & & -.222 & .015 & $-14.902 *$ \\
\hline D1920 & & & & & & & -.219 & .014 & $-15.773^{*}$ \\
\hline$D 1910$ & & & & & & & -.212 & .015 & $-13.908^{*}$ \\
\hline$D 1900$ & & & & & & & -.227 & .018 & $-12.520^{*}$ \\
\hline D1890 & & & & & & & -.186 & .034 & $-5.482 *$ \\
\hline D1880 & & & & & & & -.148 & .051 & $-2.913 *$ \\
\hline D1870_DN & & & & & & & -.091 & .054 & -1.691 \\
\hline \multicolumn{10}{|l|}{ Model Summaries } \\
\hline & & .777 & & & .791 & & & .793 & \\
\hline Adj. R2 & & .776 & & & .791 & & & .792 & \\
\hline Std. Error of Estimate & & .188 & & & .183 & & & .182 & \\
\hline Model F-Value & & 1009.93 & & & 1109.90 & & & 747.87 & \\
\hline
\end{tabular}

* Indicates significance at 01 level, using a two-tailed test.

** Indicates significance at 05 level, using a two-tailed test. 
Table 6: Regression Analysis: Dunedin City

\begin{tabular}{|c|c|c|c|c|c|c|c|c|c|}
\hline \multirow[b]{2}{*}{ Variable } & \multicolumn{3}{|c|}{ Model One (Linear) } & \multicolumn{3}{|c|}{ Model Two (Cubic) } & \multicolumn{3}{|c|}{ Model Three (Dummy) } \\
\hline & Estimate & HCSE & T-Value & Estimate & HCSE & T-Value & Estimate & HCSE & T-Value \\
\hline Intercept & 6.690 & .501 & $13.360^{*}$ & 11.245 & .114 & 98.794* & 11.523 & .122 & $94.316^{*}$ \\
\hline FloorArea & $5.23 \mathrm{E}-03$ & $1.64 \mathrm{E}-04$ & $31.959^{*}$ & $4.91 \mathrm{E}-03$ & $1.70 \mathrm{E}-04$ & $28.841 *$ & $4.88 \mathrm{E}-03$ & $1.72 \mathrm{E}-04$ & $28.425^{*}$ \\
\hline SiteArea & $6.35 \mathrm{E}-06$ & $1.93 \mathrm{E}-05$ & 0.329 & $1.60 \mathrm{E}-05$ & $1.95 \mathrm{E}-05$ & 0.820 & $1.64 \mathrm{E}-05$ & $1.96 \mathrm{E}-05$ & 0.836 \\
\hline CarParks & .045 & .008 & $5.598^{*}$ & .047 & .008 & $5.665^{*}$ & .049 & .008 & $6.064 *$ \\
\hline Log_CBD & -.067 & .009 & $-7.517 *$ & -.069 & .009 & $-7.778^{*}$ & -.068 & .009 & $-7.541 *$ \\
\hline PCInc96 & $2.68 \mathrm{E}-06$ & $1.89 \mathrm{E}-06$ & 1.419 & $3.57 \mathrm{E}-06$ & $1.83 \mathrm{E}-06$ & $1.945^{* *}$ & $3.16 \mathrm{E}-06$ & $1.84 \mathrm{E}-06$ & 1.714 \\
\hline PERC_Euro96 & .118 & .163 & 0.723 & .096 & .162 & 0.594 & .117 & .160 & 0.733 \\
\hline Water_View & .041 & .016 & $2.619^{*}$ & .042 & .016 & $2.681 *$ & .045 & .015 & $2.917^{*}$ \\
\hline EXT_ḠGOOD & .088 & .011 & $7.978^{*}$ & .075 & .011 & $6.817^{*}$ & .080 & .012 & $6.847 *$ \\
\hline EXT_POOR & -.116 & .025 & $-4.657^{*}$ & -.139 & .028 & $-5.030^{*}$ & -.128 & .026 & $-4.848 *$ \\
\hline INT_GOOD & .097 & .028 & $3.438^{*}$ & .114 & .028 & $4.103^{*}$ & .112 & .027 & $4.081^{*}$ \\
\hline INT_POOR & -.110 & .040 & $-2.771 *$ & -.127 & .040 & $-3.187 *$ & -.125 & .037 & $-3.342 *$ \\
\hline LScape_GOOD & .007 & .026 & 0.292 & .016 & .025 & 0.649 & .022 & .025 & 0.875 \\
\hline LScape_POOR & -.026 & .014 & -1.790 & -.048 & .014 & $-3.372 *$ & -.049 & .014 & $-3.485^{*}$ \\
\hline Neighbours_GOOD & .136 & .017 & $8.181^{*}$ & .123 & .016 & $7.618^{*}$ & .127 & .016 & $7.933^{*}$ \\
\hline Neighbours_POOR & -.071 & .012 & $-5.913 *$ & -.084 & .012 & $-6.987 *$ & -.085 & .012 & $-6.893^{*}$ \\
\hline Year_Built & $2.33 \mathrm{E}-03$ & $2.54 \mathrm{E}-04$ & $9.157^{*}$ & & & & & & \\
\hline Decade_centred & & & & $1.91 \mathrm{E}-03$ & $4.98 \mathrm{E}-04$ & $3.827^{*}$ & & & \\
\hline Decade_c2 & & & & $5.24 \mathrm{E}-05$ & $6.96 \mathrm{E}-06$ & $7.527^{*}$ & & & \\
\hline Decade_c3 & & & & $5.18 \mathrm{E}-07$ & $2.96 \mathrm{E}-07$ & 1.748 & & & \\
\hline$D 1980$ & & & & & & & -.072 & .035 & $-2.068 * *$ \\
\hline D1970 & & & & & & & -.229 & .032 & $-7.184 *$ \\
\hline D1960 & & & & & & & -.247 & .033 & $-7.611^{*}$ \\
\hline D1950 & & & & & & & -.270 & .033 & $-8.051 *$ \\
\hline D1940 & & & & & & & -.293 & .037 & $-8.019 *$ \\
\hline D1930 & & & & & & & -.307 & .036 & $-8.593^{*}$ \\
\hline D1920 & & & & & & & -314 & .036 & $-8.673^{*}$ \\
\hline D1910 & & & & & & & -.311 & .039 & $-8.050^{*}$ \\
\hline D1900 & & & & & & & -.334 & .040 & $-8.355^{*}$ \\
\hline D1890 & & & & & & & -.382 & .049 & $-7.745^{*}$ \\
\hline D1880_DN & & & & & & & -.391 & .072 & $-5.435^{*}$ \\
\hline \multicolumn{10}{|l|}{ Model Summaries } \\
\hline R2 & & .684 & & & .692 & & & .698 & \\
\hline Adj. R2 & & .682 & & & .690 & & & .695 & \\
\hline Std. Error of Estimate & & .220 & & & .217 & & & .216 & \\
\hline Model F-Value & & 241.32 & & & 248.58 & & & 171.82 & \\
\hline
\end{tabular}




\section{CONCLUSIONS}

The empirical evidence presented has confirmed that vintage maintains a nonlinear relationship with house value, and therefore, models using polynomial functions or a series of dummy variables can offer more explanatory power over models employing a traditional, linear specification of age- or vintage-related variables. This was anticipated and corroborates findings of previous research. In contrast, the variation in patterns of vintage effect across the four markets analysed was not anticipated by the authors. Although Auckland City and Wellington maintain quite similar vintage effects, with price premiums offered to vintage houses at and around the turn-of-the-century, Christchurch and Dunedin markets discount earlier vintages when compared to new house prices. This is particularly the case in Dunedin, which sees ever increasing discounts associated with earlier house vintages.

Although the housing stock across these four markets are somewhat similar in terms of their distribution by vintage and the physical characteristics of the stock by vintage, the markets do vary considerably in socioeconomic terms. For instance, based on the 1996 census, the per capita income for each of the four markets was $\$ 25,475$ in Auckland, $\$ 28,973$ in Wellington, $\$ 20,429$ in Christchurch, and \$18,482 in Dunedin. Related to this difference in income levels, the authors offer a hypothesis that the price premiums or discounts associated with a given vintage may relate to the gain or loss of the "psychic income" a homebuyer anticipates from ownership of the home. This expression "psychic income" originated from Fisher (1906) who, along with subsequent researchers, applied the concept to labour-related economics. The Dictionary of Marketing Terms by P. F. Anderson, et al. (1988) defines psychic income as "the intangible gratification or value that is derived from products, services, or activities, such as the improvement in a consumer's self image as a result of purchasing certain highly desirable products". For example, the purchase of popular vintage homes, such as turn-of-the-century Victorian Villas and early California Bungalows, may result in the purchaser receiving considerable psychic income which is compensated through price premiums. The authors propose that the amount of psychic income received and premium paid would likely correspond to the socioeconomic status of the homebuyer and neighbourhood where the house is located. This would inpart explain why wealthier cities witness price premiums for earlier vintages, while lower income markets offer discounts to these same vintages.

This variation in vintage effect between markets warrants further research. Such further studies should investigate vintage effect within markets at the submarket level. Perhaps wealthier, prestigious submarkets such as Parnell (Auckland) will observe a more intense vintage effect than less wealthy neighbourhoods in the same market, where the related psychic income for house vintage will likely be smaller and have less impact on sales prices. 
Another possible reason for the variation in vintage effect patterns across markets is the climate. The two markets that discount earlier vintages in comparison with new houses, Christchurch and Dunedin, are located in New Zealand's South Island which sustains colder temperatures in the winter. Prior to a 1977 revision to the New Zealand Building Code, thermal insulation was not required and as a result many older New Zealand homes, particularly early villas and bungalows, have little or no thermal insulation. It is possible that such older houses in less wealthy markets may not have been insulated in subsequent renovations to the same extent that their counterparts in Auckland and Wellington were. Since insulation is generally hidden within the wall, floor, and ceiling cavities, its existence would likely not have been reflected in the valuer's measure for interior condition of fixtures and finishes. Therefore, the set of vintage variables in the hedonic model would also serve as proxy for any lack of thermal insulation. Inadequate insulation would result in higher winter heating bills which, for homebuyers on tight budgets, may justify some of the pricing discounts for earlier vintage houses in these southern markets.

Overall, the present study has uncovered much intriguing phenomenon related to vintage effects, which warrant further investigation. The immediate findings and methodology of the present study, however, should be of particular benefit to local authorities charged with maintaining property valuation rolls. By adopting one of the nonlinear specifications for house vintage proposed in this paper, the accuracy of the mass appraisal models used to assess properties for ad valorem taxation can be improved. The result would be more equitable property taxation and a reduction in the number of objections to valuation brought on by inaccurate assessments.

\section{REFERENCES}

Anderson, P. F. et al. (1988) in Bennett, P. D. (ed.), Dictionary of Marketing Terms, Chicago: American Marketing Association.

Arnott, R., Davidson, R. and Pines, D. (1983) Housing Quality, Maintenance and Rehabilitation, The Review of Economic Studies, 50 (3), pp. 467-494.

Bates, D. M. and Watts, D. G. (1988) Nonlinear Regression Analysis and its Applications, New York: Wiley.

Chinloy, P. (1980) The Effect of Maintenance Expenditures on the Measurement of Depreciation in Housing. Journal of Urban Economics, 8, pp. 86-107.

Clapp, J. M. and Giaccotto, C. (1998) Residential Hedonic Models: A Rational Expectations Approach to Age Effects. Journal of Urban Economics, 44, pp. 415-437. 
Epley, D. R. (1990) The Concept and Market Extraction of Effective Age for Residential Properties. Journal of Real Estate Research, 5 (1), pp. 41-52.

Do, A. Q. and Grudnitski, G. (1993) A Neural Network Analysis of the Effect of Age on Housing Values. Journal of Real Estate Research, 8 (2), pp. 253-264.

Fisher, I. (1906) The Nature of Capital and Income, New York: Kelly.

Goodman, A. C. and Thibodeau, T. G. (1995) Age-Related Heteroskedasticity in Hedonic House Price Equations. Journal of Housing Research, 6 (1), pp. 25-42.

Goodman, A. C. and Thibodeau, T. G. (1997) Age-Related Heteroskedasticity in Hedonic House Price Equations: An Extension. Journal of Housing Research, 8 (2), pp. 299-317.

Goodman, A. C. and Thibodeau, T. G. (1998) Dwelling Age Heteroskedasticity in Repeat Sales House Price Equations. Real Estate Economics, 26 (1), pp. 151-171.

Guasch, J. L. and Marshall, R. C. (1985) Age of Rental Housing Units and Vacancy Characteristics: A Filtering Explanation. Regional Science and Urban Economics, 15, pp. 403-419.

Hall, R. E. (1968) Technical Change and Capital from the Point of View of the Dual. The Review of Economic Studies, 35, pp. 35-46.

Hall, R. E. (1971) 'The Measurement of Quality Change from Vintage Price Data' in Griliches, Z. (ed.), Price Indexes and Quality Change: Studies in New Methods of Measurement, Cambridge: Harvard University Press.

Hayes, A. F. and Cai, L. (2006) Using Heteroscedasticity-Consistent Standard Error Estimators in OLS Regression: An Introduction and Software Implementation. Working paper, Ohio State University.

Knight, J. R. and Sirmans, C. F. (1996) Depreciation, Maintenance, and Housing Prices. Journal of Housing Economics, 5, pp. 369-389.

Long, J. S. and Ervin, L. H. (2000) Using Heteroscedasticity Consistent Standard Errors in the Linear Regression Model. The American Statistician, 54 (3), pp. 217-224.

Lowry, I. S. (1960) Filtering and Housing Standards, A Conceptual Analysis. Land Economics, 35, pp. 362-370.

Malpezzi, S., Ozanne, L. and Thibodeau, T. G. (1987) Microeconomic Estimates of Housing Depreciation. Land Economics, 63 (4), pp. 372-385. 
Margolis, S. E. (1981) Depreciation and Maintenance of Houses. Land Economics, 57 (1), pp. 91-105.

Muth, R. F. (1973) A Vintage Model of the Housing Stock. Papers of the Regional Science Association, 30, pp. 141-156.

Randolph, W. C. (1988) Estimation of Housing Depreciation: Short-Term Quality Change and Long-Term Vintage Effects. Journal of Urban Economics, 23, pp. 162-178.

Rubin, G. M. (1993) Is Housing Age a Commodity? Hedonic Price Estimates of Unit Age. Journal of Housing Research, 4 (1), pp. 165-184.

Sabella, E. M. (1974) Determining the Relationship between a Property's Age and its Market Value. Assessors Journal, January, pp. 81-85.

Sabella, E. M. (1975) The Effect of Age on Change in Property Value. Assessors Journal, April, pp. 3-6.

Sirmans, G. S., Macpherson, D. A. and Zietz, E. N. (2005) The Composition of Hedonic Pricing Models. Journal of Real Estate Literature, 13 (1), pp. 4-43.

U.S. Department of Housing and Urban Development (1990) American Housing Survey. Washington, D.C.: U.S. Department of Housing and Urban Development.

Waddell, P., Berry, B. and Chung, K. (1996) Variations in Housing Price Depreciation: The "Taste for Newness" Across Heterogeneous Submarkets. Urban Geography, 17 (3), pp. 269-280.

White, H. (1980) A Heteroskedasticity-Consistent Covariance Matrix Estimator and a Direct Test for Heteroskedasticity. Econometrica, 48 (4), pp. 817-838. 